Suárez de Garay, María Eugenia. (2016).

"Los policías: Una averiguación antropológica".

Guadalajara, México: ITESO. 490 páginas.

Recuperado de: http://hdl.handle.net/11117/3842

\title{
Los policías: Una averiguación antropológica
}

"Los policías: Una averiguación antropológica" de la mexicana María Eugenia Suárez de Garay, Doctora en Antropología Social y Cultural de la Universidad Autónoma de Barcelona, es una muestra formidable de las transformaciones que se han dado en América Latina, en tiempos recientes: las mujeres incursionaron en la seguridad pública y en los asuntos policiales, campos reservados en otros tiempos para los hombres, tanto en su discurso como en sus prácticas.

Este texto es un referente bibliográfico obligado para hombres y mujeres del ámbito público o privado que desde su calidad de ciudadanos tengan que interactuar con la Policía en la vida cotidiana en tópicos concernientes con los derechos humanos, los derechos y deberes en el Estado de derecho, la protección de la vida en todas sus dimensiones, el cuidado de los bienes, la conservación de la tranquilidad en el vecindario, entre otros para los que está creada la Policía moderna, objeto y sujeto de investigación de la autora, que ha dedicado largos años a estudiar el rol de la policía y plantear propuestas para cualificar su necesaria existencia en la democracia.

La autora goza de una larga trayectoria académica, investigativa y de trabajo con diversos cuerpos policiales del continente y, producto de ello, este trabajo es una radiografía maestra de sus profundos conocimientos sobre este organismo de control facultado en el Estado de derecho para conservar el orden social, que hoy presenta condiciones anómicas ante la baja confianza de la población en sus autoridades protagonistas de acciones de corrupción y la lucha desleal por el poder político. En este modelo, la Policía también parece sentirse con el aval para ejercer su ostentoso poder con el máximo de arbitrariedad.

En este estudio, producto de diez años de observación sistemática de la autora en los escenarios de acción de la Policía Preventiva de Guadalajara, en el Estado de Jalisco, México; Suárez de Garay, desde los filtros de la antropología cultural que deja ver los modos de pensar y hacer de los individuos en un contexto, explora los significados que los policías le dan a sus acciones y presenta hallazgos que obligan a cualquier lector a percibir 


\section{WEB}

a los uniformados como personas, miembros de una familia, ciudadanos y, sobre todo, representantes legítimos de la sociedad y cultura a la también nosotros pertenecemos.

Estos individuos, al incorporarse a la fuerza pública, asumen valores, prácticas, creencias y roles institucionales revestidos de poder para vigilar el cumplimiento de los parámetros normativos establecidos para la conservación del orden social, mediante su contacto directo con los particulares. En tal contexto, sociológicamente, la institución de vigilancia es un organismo social representativo de la sociedad que la engendra: nace, evoluciona y puede morir sumida en vicios heredados de la misma, pero especialmente de los actores políticos que la administran. La Policía es un organismo en constante cambio, o mejor adaptación, de sus funciones según la interacción entre la sociedad civil y la sociedad política. En México y el Estado de Guadalajara, la fuerza pública se ha apropiado más antivalores que valores de la sociedad política, en la que predominan las prácticas favorables al bien común que predican en épocas electorales, camuflados con las bondades de la democracia participativa.

La preocupación de la autora sobre los vicios y virtudes de la Policía como institución puente entre los gobernantes y la ciudadanía se somete a un rigor académico del que emergen respuestas que exigen conocer la génesis de policía moderna en el siglo XIX, cuando la Declaración de los Derechos del Hombre y del Ciudadano (1789) motivó la necesidad de disponer de una Fuerza Pública para vigilar su cumplimiento, tarea que hoy, según la investigadora, tanto en Guadalajara como en todo México cuenta con enormes vacíos ante la arbitrariedad en sus procesos, la actuación violenta por parte de algunos de sus uniformados y el vínculo de altos y bajos mandos a conductas de corrupción. La distancia entre la ciudadanía y estos reguladores del orden cada vez aumenta. Su falta de legitimidad también se aduce a la escasa capacitación para la comprensión y vivencia de sus funciones; así como a la exposición de índices de gestión cuantitativos al margen del conocimiento de las dinámicas propias del conflicto y la concentración de su acción en indicadores delictuales, que justamente son el reflejo de la prevención como primera función de este organismo.

La mirada fría de la estructura policial conforme a los lineamientos constitucionales del Estado de Jalisco, en este caso, y los vacíos en el servicio a la comunidad como elementos constitutivos del ser y hacer público, recobran un sentido humano cuando la investigadora se acerca a cada uniformado a través de entrevistas de profundidad, en el marco de un diario de campo, para entrar a su propia historia de familia, sus sueños y razones para ser parte de las fuerzas del orden. Esta exploración de 
sentimientos, pensamientos y práctica, tomando planteamientos teóricos y conceptuales de Alfred Schutz y Thomas Luckmann, le permiten obtener hallazgos valiosos sobre el mundo interno de la Policía en el que ellos se sienten representados en sus proyectos personales; así mismo se conocen las estrategias implementadas en esta "gran familia" para manejar las representaciones sociales -casi siempre negativas- de las comunidades frente a su ser y hacer. Lo cierto es que en este entramado entre la vida interna institucional y la vida externa que los uniformados experimentan se vive una situación de incongruencia donde la ética no es el parámetro fundamental para la protección de los residentes y visitantes del país.

Según Suárez de Garay, los policías gozan de un alto grado de discresionalidad para su actuación desde la que fortalecen la existencia de un infraestado en el que ciudadanos son subordinados de las fuerzas del orden y, muchas veces, obligados a participar de la cadena de ilegalidad que inicia con la omisión o extralimitación del policía y termina con en la construcción de una cultura de la desesperanza de la población ante la acción efectiva de la justicia y el castigo a los delincuentes por mano propia.

La investigación muestra resultados cuidadosamente organizados del análisis de discursos, prácticas y significados que los policías atribuyen a sus modos con los que abordan el control social y se relacionan en su vida institucional. Así mismo se muestra la construcción de un ser, saber, y hacer propio a partir de sus experiencias de las que extraen aprendizajes. En tal sentido cada miembro de la institución también es un sujeto histórico constructor de conocimiento continuo en su interacción entre el mundo interior y el exterior al organismo.

Aunque la autora considera su obra como un aporte insuficiente para entender el rol de la Policía en los Estados democráticos contemporáneos y el aporte de sus miembros a una cultura de la legalidad y la no violencia, lo cierto es que esta investigación antropológica, salvo mejor juicio, se constituye en el referente bibliográfico para gobernantes interesados en el bien común, directivos y docentes de las escuelas policiales, investigadores sociales interesados en la transformación sociopolítica de nuestros territorios y demás actores interesados en aportar al hacer constitucional de la justicia a partir del pacto de los Derechos Humanos que cobija tanto al mundo interno de la Institución como al mundo externo en donde están los ciudadanos, razón de ser de su oficio. 


\section{WEB}

Los resultados, situados en Guadalajara, México, son válidos para la misma situación de los cuerpos policiales de los demás países de la región, en el que se exceptúan muy pocos que ya obedecen a su conciencia moral y lineamientos de la Ley como parámetro de actuación congruente con el bien común. Si a ello se suma la voluntad político de los gobernantes, en pronto tiempo tendremos ciudadanos -policías orgullosos de su profesión y sociedades seguras que confían en sus guardianes, según María Eugenia, libres del miedo.

Sinopsis elaborada por María Stella Baracaldo Méndez

Secretaría de Gobierno del Departamento de Cundinamarca, Colombia 